\title{
Factors Related to the Risk of Meniscal Injury in Dogs with Cranial Cruciate Ligament Rupture
}

\author{
A. NEČAS ${ }^{1}$, J. ZATLOUKAL ${ }^{2}$
}

${ }^{1}$ Department of Surgery and Orthopedics, ${ }^{2}$ Department of Diagnostic Imaging, Small Animal Clinic, University of Veterinary Medicine,

University of Veterinary and Pharmaceutical Sciences, Brno, Czech Republic

Received September 25, 2001

Accepted February 13, 2002

\section{Abstract}

Nečas A., J. Zatloukal: Factors Related to the Risk of Meniscal Injury in Dogs with Cranial Cruciate Ligament Rupture. Acta Vet. Brno 2002, 71: 77-84.

Risk factors for damage of the medial meniscus in 160 cranial cruciate deficient stifles in 138 dogs have been evaluated. The medial meniscal damage was found in a total of 72 patients (45\%) with CCL rupture. The risk of damage to the meniscus was significantly higher in dogs of 25-45 kg compared to those weighing less than $24 \mathrm{~kg}$. Cases of more severe grades of arthritis and joint effusion were significantly more often accompanied by the medial meniscal damage. Severe osteoarthritis of grade 3 , as compared to the grade 1 , was considerably frequently $(p<0.01)$ associated with the medial meniscal lesion. The meniscal damage was most commonly accompanied by moderately severe stifle joint effusion. The medial joint cavity collapse was a very important radiographic sign expressing the medial meniscal damage $(p<0.01)$. Its sensitivity and specifity in the diagnostics of the medial meniscal damage is $52 \%$ and $71 \%$, respectively. Duration of lameness, extent of the CCL rupture (partial versus total) and radiographically measured index of the stifle joint laxity do not belong to statistically significant risk factors of the medial meniscal damage.

Meniscus, knee, stifle instability, osteoarthritis, effusion, joint space

In contrast to the situation in humans, primary damage of menisci in dogs is rare, meniscal injury secondary to cruciate or collateral ligament ruptures, however, is common (Piermattei and Flo 1997). Reports of lateral meniscal injury are sporadic (Hohn and Newton 1975). Most frequently, the medial meniscus is involved due to cranial cruciate ligament (CCL) rupture (Pearson 1971; Piermattei and Flo 1997; Scavelli et al. 1990). Breed, age, sex and body weight as risk factors for the rupture of the cranial cruciate ligament in dogs have been determined (Duval et al. 1999; Nečas et al. 2000; Whitehair et al. 1993). To our knowledge the risk factors have not yet been evaluated for injury of the medial meniscus. Meniscal damage may be acute or degenerative and usually involves the caudal and medial portions of the medial meniscus (Arnoczky 1993; Pearson 1971). The medial meniscus is damaged as a result of the cranial tibial drawer motion in the unstable cruciate-deficient knee, because it is firmly attached to the tibia by the caudal tibial ligament and to the medial collateral ligament. Cranial drawer movement displaces the caudal horn of the medial meniscus cranially to the medial femoral condyle and subjects the meniscus to injury during weight bearing. The cranial drawer motion in the extended knee is much more injurious to the medial meniscus than it is in flexion (Stone et al. 1980).

The incidence of meniscal injuries following rupture of the cranial cruciate ligament can be as high as 53\% (Flo and De Young 1978), 61\% (Scavelli et al. 1990), and greater than 76\%, respectively (Flo 1993; Timmermann et al. 1998). Piermattei and Flo (1997) found that this incidence reflects a predominance of chronic cases of CCL rupture seen in a referral practice.

The definitive diagnosis of the meniscal injury is made by observing the abnormally

Address for correspondence:

Doc. MVDr. Alois Nečas, Ph.D

Department of Surgery and Orthopedics, Small Animal Clinic

University of Veterinary and Pharmaceutical Sciences

Palackého 1-3, 61242 Brno, Czech Republic
Phone: +420602742484

Fax: +4205 41562344

http://www.vfu.cz/acta-vet/actavet.htm 
displaced meniscus or portion of it by arthrotomy or arthroscopy. Radiography has not been a reliable diagnostic method for this condition (Piermattei and Flo 1997). Early surgical intervention (arthrotomy or arthroscopically assisted surgery) and removal of the damaged portion of the meniscus is indicated in patients with meniscal injury in the cranial cruciatedeficient stifle to prevent severe degenerative joint disease (Beale and Hulse 2000; Hulse 2001; Hulse and Beale 2000; Vasseur 1993). Piermattei and Flo (1997) state, that early surgical treatment of the cruciate-deficient stifle results in a much lower incidence of meniscal injury. Stifle joint instability as a result of ligamentous insufficiency leads to degenerative lesions of the menisci, even when there is no primary meniscal injury (Arnoczky et al. 1979). On the other hand, it has been published that removal of a normal medial meniscus in otherwise intact stifles creates some degenerative changes in the joint (Cox et al. 1975; De Young et al. 1980). These findings suggest that different factors may predispose to the meniscal damage. Risk factors of meniscal injury are not completely documented in the veterinary literature.

The goal of this study was to determine factors related to the risk of medial meniscus injury in unstable stifle joints due to cranial cruciate ligament rupture in dogs.

\section{Materials and Methods}

A total number of 160 stifle joints affected by the cranial cruciate ligament rupture in 138 dogs were treated surgically at the Department of Surgery and Orthopedics (Small Animal Clinic, University of Veterinary and Pharmaceutical Sciences Brno) during the period from March 1998 to August 2001. The diagnosis of the cranial cruciate ligament rupture was determined by arthrotomy or arthroscopy. During the surgery, the degree of the cranial cruciate ligament damage (partial or total rupture) and damage to the medial meniscus (damaged or intact) were determined. The signalment and history included age of the dog ( $\leq 3$ years, 4-6 years, $\geq 7$ years), body weight of the patient $(<10 \mathrm{~kg}, 10-24 \mathrm{~kg}, 25-45 \mathrm{~kg},>45 \mathrm{~kg})$, sex (male or female), side of the damage (right or left) and duration of lameness ( $\leq 1$ week, 2-4 weeks, 5-12 weeks and $\geq 13$ weeks). Orthopaedic examination included determination of the grade of lameness based on the following five-level scale (0 to 5$)$ used in our clinic to classify lame patients (Nečas et al. in print):

0 : normal weight-bearing on all limbs at rest and when walking - i.e., "no lameness"

1: partial weight bearing at rest (it does not stand on the main footpad, but stands on the digital pads), normal when walking, lameness at trot - i.e., mild lameness"

2: partial weight bearing at rest and when walking - i.e., "moderate lameness"

3: partial weight bearing at rest and no weight bearing when walking - i.e., moderately severe lameness"

4: no weight bearing at rest and when walking - i.e., "severe lameness"

5: reluctant to rise and will not walk more than 5 strides - i.e., "very severe lameness"

Two mediolateral projections of the stifle joint using the technique by De Rooster et al. (1998) and a standard caudocranial projection of the stifle joint (Morgan 1993) were made. The stifle joint in the mediolateral projection was radiographed in its neutral position $\left(90^{\circ}\right.$ flexion in the stifle approximately). For the purpose of the study, the stifle joint was radiographed in a second projection, i.e., in maximum flexion of the tarsal joint (stress tibial compression projection). All radiographs were taken in patients in a deep sedation using a combination of medetomidine (10-20 $\mu \mathrm{g} / \mathrm{kg}$ i.v.) and butorphanol $(0.2 \mathrm{mg} / \mathrm{kg}$ i.v.) or overall inhalation anaesthesia. Patients for the stress projection were positioned by one radiologist (Zatloukal). Radiographs were taken by a technique of low voltage $(45-60 \mathrm{kV})$, table top, without the grid, using cassettes of fortifying foils with the intensifying factor of 100 to obtain high-detail resolution, focal distance of standard $75 \mathrm{~cm}$. The mediolateral neutral projection served the purpose of determining the degree of osteoarthritis (OA), effusion and calcification of the cranial cruciate ligament. The degree of osteoarthritis was evaluated using the criteria by Brunnberg et al. (1992) classifying the overall osteoarthritis as of grade O ( no OA changes), grade 1 (mild OA, osteophytes in the distal patella, sclerosis and osteophytes of the trochlear ridge), grade 2 (moderate OA, osteophytes in the distal and proximal patella, sclerosis and osteophytes of the trochlear ridge, osteophytes in the area of fabellae and sclerosis of the tibial plateau), grade 3 (severe OA, the same signs as in grade 2, but of greater extent plus osteophytes in the caudal tibial plateau and sulcus of $\mathrm{m}$. extensor digitorum longus). The degree of joint effusion was determined on the basis of evaluation of the caudal joint capsule distension and the distance the subpatellar fat is pushed away from femoral condyles by the joint fluid. The joint effusion was then classified as of grade 0 (without effusion), grade 1 (mild effusion), grade 2 (moderate effusion) or grade 3 (severe effusion). This evaluation was considerably subjective, without strict criteria. Regarding the fact that all radiographs were evaluated by one radiologist (Zatloukal), we can consider even these subjective criteria to be uniform and sufficient for our study. Comparing the neutral mediolateral and stress tibial compression projections we determined the index of laxity of the stifle joint using the technique by Zatloukal et al. (2000). Stifle joints were 
classified into three groups $(<25,25-50,>50)$ using the index of laxity. On the caudocranial projection we evaluated collapse of the medial joint cavity as compared to the lateral joint space (collapse, no collapse). These radiographs were evaluated by the radiologist irrespective of the history and clinical examination and recorded prior to surgery.

For each of the possible risk factors we compared individual groups with each other using the $\chi^{2}$-test with regards to the occurrence of medial meniscal damage. In cases where we compared three and more groups, the basic group was the one with the highest number of joints examined to which all other groups were compared. The difference between groups was considered as significant at the level of $p<0.05$. Odds ratio indicates the probability of meniscal injury in comparison to the control group (the one being most numerous). Values over 1.0 indicate higher risk, whereas values lower than 1.0 mean lower risk.

\section{Results}

Out of the total of 160 stifle joints with the CCL rupture treated, in all, 72 (45\%) cases were accompanied by damage to the medial meniscus.

Age, sex and side of the lesion in the patient did not influence the rate of risk of the medial meniscus damage in our study.

As the body weight of the patients grew, the risk of medial meniscal damage increased. Compared to the group of dogs of $25-45 \mathrm{~kg}$ of body weight, there was a significantly lower risk in the group of dogs weighing $<10 \mathrm{~kg}$ and $10-24 \mathrm{~kg}(p<0.05)$.

As the duration of lameness grew, the risk of medial meniscal damage also increased, the fact, however, being not so important as to determine the duration of lameness as an important risk factor.

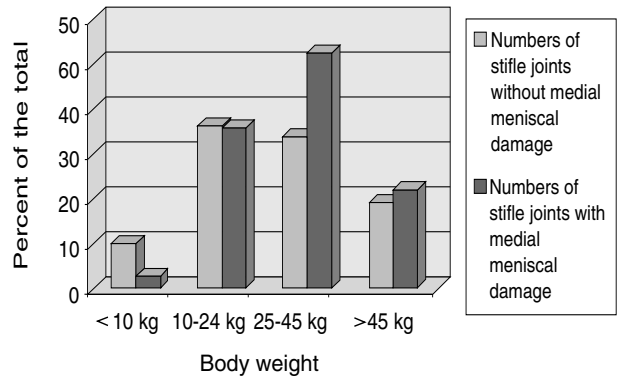

Fig. 1. Body weight at the time of CCL rupture as a risk factor for the medial meniscal damage

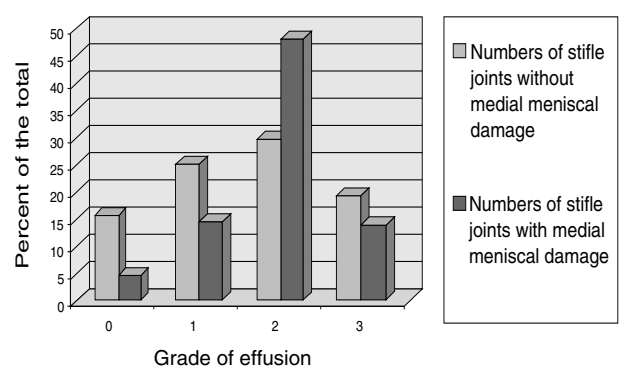

Fig. 2. Grade of effusion as a risk factor for the medial meniscal damage

Even when there was a significantly lower frequency of medial meniscal damage in one grade of lameness (i.e., grade 3 ) compared to the most common grade of lameness (grade 2 ), it was not possible to uncover a general relation between the grade of lameness and medial meniscal damage. We had to exclude some cases both from the data on the duration of lameness and the grade of lameness mostly because of bilateral affections influencing the evaluation in a negative way.

The grade of OA was not accompanied by a significant rise in the risk of medial meniscal damage except for the severe osteoarthritis (grade 3) which was considerably more frequently $(p<0.01)$ in relation with medial meniscal damage than the mild OA grade 1 .

Stifle joints without effusion or only with a mild effusion were not so often accompanied by the medial meniscal damage as the most frequently occurring moderate effusion cases $(p<0.05)$.

The medial joint cavity collapse was found to be a very important radiographic sign expressing the higher risk of medial meniscal damage $(\mathrm{p}<0.01)$. As far as the diagnostics of medial meniscal damage is concerned, this radiographic sign was $52 \%$ sensitive and $71 \%$ specific. 
Table 1

Factors related to the risk of meniscal injury in dogs with cranial cruciate ligament rupture

\begin{tabular}{|c|c|c|c|c|}
\hline Risk factor & $\begin{array}{c}\text { No. of stifle joints } \\
\text { without meniscal } \\
\text { damage }\end{array}$ & $\begin{array}{c}\text { No. of stifle joints } \\
\text { with meniscal } \\
\text { damage }\end{array}$ & Odds ratio & $\begin{array}{l}\text { Probability values } \\
\quad\left(\chi^{2} \text {-test }\right)\end{array}$ \\
\hline \multicolumn{5}{|l|}{ Age } \\
\hline$\leq 3$ years $\square$ & 35 & 35 & 1.00 & NA \\
\hline 4-6 years & 21 & 22 & 1.05 & NS \\
\hline$\geq 7$ years & 32 & 15 & 0.47 & NS \\
\hline \multicolumn{5}{|l|}{ Body weight } \\
\hline$<10 \mathrm{~kg}$ & 9 & 2 & 0.18 & $p<0.05$ \\
\hline $10-24 \mathrm{~kg}$ & 32 & 26 & 0.39 & $p<0.05$ \\
\hline $25-45 \mathrm{~kg}$ & 30 & 38 & 1.00 & NA \\
\hline$>45 \mathrm{~kg}$ & 17 & 16 & 0.74 & NS \\
\hline \multicolumn{5}{|l|}{ Sex } \\
\hline Male $\mathbf{\square}$ & 50 & 39 & 1.00 & NA \\
\hline Female & 38 & 33 & 1.11 & NS \\
\hline \multicolumn{5}{|l|}{ Site } \\
\hline Right stifle joint $\mathbf{\square}$ & 39 & 24 & 1.00 & NA \\
\hline Left stifle joint & 49 & 48 & 1.59 & NS \\
\hline \multicolumn{5}{|l|}{ Duration of lameness } \\
\hline$\leq 1$ week $\mathbf{\square}$ & 28 & 15 & 1.00 & NA \\
\hline $2-4$ weeks & 29 & 22 & 1.42 & NS \\
\hline 5-12 weeks & 15 & 19 & 2.36 & NS \\
\hline$\geq 13$ weeks & 10 & 10 & 1.87 & NS \\
\hline Missing data & 6 & 6 & - & - \\
\hline \multicolumn{5}{|l|}{ Grade of lameness } \\
\hline 0 & 2 & 1 & 0.55 & NS \\
\hline 1 & 3 & 2 & 0.74 & NS \\
\hline $2 \mathbf{\square}$ & 53 & 48 & 1.00 & NA \\
\hline 3 & 12 & 3 & 0.27 & $p<0.05$ \\
\hline 4 & 7 & 5 & 0.79 & NS \\
\hline 5 & 0 & 3 & NA & NA \\
\hline Missing data & 11 & 10 & - & - \\
\hline \multicolumn{5}{|l|}{ Grade of osteoartritis } \\
\hline 0 & 25 & 12 & 0.72 & NS \\
\hline $1 \mathbf{0}$ & 30 & 20 & 1.00 & NA \\
\hline 2 & 25 & 17 & 1.02 & NS \\
\hline 3 & 4 & 14 & 5.25 & $p<0.01$ \\
\hline Missing data & 4 & 9 & - & - \\
\hline \multicolumn{5}{|l|}{ Grade of effusion } \\
\hline 0 & 14 & 3 & 0.16 & $p<0.05$ \\
\hline 1 & 22 & 10 & 0.34 & $p<0.05$ \\
\hline $2 \mathbf{\square}$ & 26 & 35 & 1.00 & NA \\
\hline 3 & 17 & 10 & 0.43 & NS \\
\hline Missing data & 8 & 14 & - & - \\
\hline \multicolumn{5}{|c|}{ Medial joint space collapse } \\
\hline No $\square$ & 58 & 29 & 1.00 & NA \\
\hline Yes & 25 & 32 & 2.56 & $p<0.01$ \\
\hline Missing data & 5 & 11 & - & - \\
\hline \multicolumn{5}{|l|}{ Index of laxity } \\
\hline$<25$ & 12 & 5 & 0.32 & NS \\
\hline $25-50 \mathbf{\square}$ & 16 & 21 & 1.00 & NA \\
\hline$>50$ & 18 & 11 & 0.47 & NS \\
\hline Missing data & 42 & 35 & - & - \\
\hline \multicolumn{5}{|c|}{ Grade of cranial cruciate ligament rupture } \\
\hline Total rupture $\square$ & 69 & 64 & 1.00 & NA \\
\hline Partial rupture & 19 & 8 & 0.45 & NS \\
\hline
\end{tabular}

Explanations: $\mathbf{\square}=$ Reference category; NA = Not applied; NS = Not significant 
The degree of the stifle joint laxity measured by the index of laxity was not found to be related to the risk of medial meniscal damage. Stress projections were not obtained during the first half of the study period. In cases in which radiographs were not taken in our clinic, the other radiographic criteria were not evaluated, as well. When the radiographic examination was preceded by intraarticular administration or puncture of the joint to collect the synovial fluid, the grade of effusion was not evaluated.

Even when we found nearly twice as more

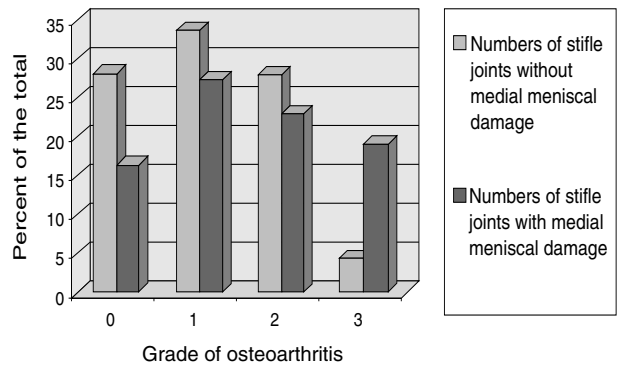

Fig. 3. Grade of osteoarthritis as a risk factor for the medial meniscal damage

frequent occurrence of medial meniscal damage in stifle joints affected by the total CCL rupture as compared to the partial rupture, the difference was not statistically significant. Table 1 summarises all the data.

\section{Discussion}

The study confirmed that dogs weighing $24 \mathrm{~kg}$ and less have significantly lower risk of medial meniscal damage than those ones weighing 25 to $45 \mathrm{~kg}$. We, therefore, conclude that the meniscal damage is considerably dependent on the body weight which the dog loads the meniscus in the unstable stifle joint. This finding is probably in accordance with the less frequent (even when not significant) meniscal damage in dogs of 7 years and older. It is known that the CCL rupture in small and medium dog breeds occurs mainly in older individuals (Duval et al. 1999; Nečas et al. 2000; Whitehair et al. 1993).

It is generally stated that in longer lasting lameness the frequency of meniscal injury goes up to $80 \%$ of all the CCL rupture cases (Flo 1993; Gambardella et al. 1981; Timmermann et al. 1998;). In our study we found some rise in the risk of meniscal damage in $\log _{s}$ that were lame for a longer period, this rise, however, was not statistically significant and amounted to much lower levels than in the papers mentioned.

Contrary to our results, Piermattei and Flo (1997) state that patients with meniscal damage show more pronounced lameness. This controversy may be caused by differences in the classification scale of lameness used. In our clinical practice and for the purpose of this study we used a 5-grade scale of lameness classification which gives emphasis on severe cases of lameness (Nečas et al. in print). It would certainly be interesting to compare this finding with those of others which classify the medium lameness cases in greater detail (Sumner-Smith 1993).

Stifles affected by the partial CCL rupture are less frequently affected by meniscal damage than joints with the total rupture. Scavelli et al. (1990) mention 20\% occurrence of meniscal lesions accompanying partial CCL rupture, whereas the frequency of meniscal damage in stifles affected by total CCL rupture varies from 53 to $76 \%$ of cases (Flo 1993; Flo and De Young 1978). In our study, it must be admitted, we found the risk of meniscal damage in stifles affected by the partial CCL rupture to be half of that in stifles with the total rupture, it is not, however, a statistically significant risk factor. We also did not prove a rise in the risk of medial meniscal damage in relation to the growing joint laxity (measured by radiography in our study). It is in accordance with other papers (De Rooster et al. 1998; Zatloukal et al. 2000) which did not prove a difference in the instability of the joint with medial meniscal damage and intact ones. On the basis of our study (and some others) it seems that the grade of joint instability is not a decisive factor for the meniscal damage. 
We proved significantly that the higher frequency of medial meniscal damage is in relation with more severe grade of arthritis and effusion. It is still a question whether the medial meniscal lesion is the cause of more severe arthritis or rather a sequel of it. The hypothesis, that the medial meniscal damage due to joint instability in the stifle with the CCL rupture is the cause of development of more severe arthritis, can be supported by our results concerning more frequent higher grades of arthritis and effusion in heavier dogs. This fact may be explained by the supposition of stronger forces of load on a relatively fixed medial meniscus in heavier and more robust breeds of dogs bearing weight on the unstable stifle joint affected by the CCL lesion. Several authors point out the fact that more severe arthritis develops in the stifle due to the meniscal lesion. It was proved that partial and total meniscectomy lead to the development of microscopic and macroscopic degenerative lesions of the joint cartilage both in the femur and tibia (Arnoczky 1993; Cox et al. 1975). The study by Cox et al. (1975) indicates that the extent of degenerative changes of the joint cartilage may be in direct relation to the size of the meniscus excised. On the other hand, the possibility of pathological lesion development in the meniscus due to the instability of the joint affected by arthritis cannot be excluded. The sliding movement of the medial femoral condyle over the medial meniscus and the pressure against the tibial plateau in the unstable stifle joint result in a non-physiological load and subsequent degeneration of the fibrous meniscal cartilage. It was described that damage to the ligament and subsequent instability of the stifle lead to the development of changes in the meniscus in a form of horizontal cleavage degenerative lesions even without primary injury (Arnoczky 1993; Arnoczky et al. 1979). These minute cleavage lesions in the meniscus may change into macroscopically visible ones (Noble and Hamblen 1975).

Collapse of the joint cavity is one of the main radiographic signs of osteoarthritis. Its evaluation should be done using radiographs of the stifle in caudocranial or craniocaudal projections. Prior to the development of very severe changes, the evaluation is possible only in weight bearing or simulated weight bearing studies (Morgan 1988). In our study, only subjective comparisons of differences, such as a clearly visible narrowing of the medial joint cavity in comparison to the lateral one, were made. The standard non-weight bearing projection was satisfactory for this purpose. We proved that the medial joint cavity, as compared to the lateral one, is significantly more frequently $(p<0.01)$ narrower in stifle joints affected by medial meniscal damage. There may be several causative factors of this collapse of the medial joint cavity. The first of them is positioning of the limb and taking really a precise projection. It seems, however, less probable that positioning of patients could differ so markedly in those ones affected by the medial meniscal damage as compared to the intact ones. This narrowing of the medial joint cavity has to be caused either by thinning of the joint cartilage of the medial femoral condyle and the medial part of the tibial plateau neighbouring with the meniscus damaged or directly by damage to the meniscus which becomes crashed and destructed or displaced. In the human medical papers there prevails the opinion that the initial narrowing of the medial joint cavity is rather a sequel to meniscal lesions than thinning of the cartilage (Adams et al. 1999). Although the collapse of the medial joint cavity is the only really important criterion for the diagnosis of the medial meniscal damage in the dog, clinical practice use is hampered by low specifity (71\%) and, especially, low sensitivity (52\%) (Table 1$)$.

\section{Rizikové faktory pro poškození mediálního menisku u psů s rupturou předního zkříženého vazu}

Rizikové faktory poranění mediálního menisku byly stanoveny ve 160 př́ipadech ruptury předního zkříženého vazu u 138 psů. Poškození mediálního menisku bylo zjištěno v 72 př́ipadech $(45 \%)$ ruptur CCL. 
U psů s hmotností 25-45 kg bylo riziko poranění menisku signifikantně vyšší než u psů vážících méně než $24 \mathrm{~kg}$. Se zvyšujícím se stupněm artrózy a efuze docházelo ke statisticky významnému zvýšení četnosti poškození mediálního menisku. Těžká osteoartritida (stupeň 3) byla s lézí mediálního menisku spojena výrazně častěji $(p<0,01)$ než mírný první stupeň osteoartritidy. Poranění menisku doprovázela nejčastěji středně výrazná efuze kolenního kloubu. Kolaps mediální kloubní štěrbiny byl velmi významným rentgenologickým příznakem poškození mediálního menisku $(p<0,01)$. V diagnostice poranění menisku by jeho senzitivita byla $52 \%$ a specifita $71 \%$.

Doba a stupeň kulhání, rozsah ruptury CCL (parciální vs. totální) a rentgenologicky měřená laxita kolenního kloubu nepatří mezi statisticky významné rizikové faktory poranění menisku.

\section{Acknowledgements}

This work was supported by the Ministry of Education, Youth and Sports of the Czech Republic (Research Project No. 161700002)

\section{References}

ADAMS, J. G., McALINDON, T., DIMASI, M., CAREY, J., EUSTACE, S. 1999: Contribution of meniscal extrusion and cartilage loss to joint space narrowing in osteoarthritis. Clin. Radiol. 54: 502-506

ARNOCZKY, S. P. 1993: Pathomechanics of cruciate ligament and meniscal injuries. In: BOJRAB, M. J.: Disease mechanisms in small animal surgery.d' $2^{\text {nd }}$ ed. Lea Febiger, Philadelphia, pp. 764-776

ARNOCZKY, S. P., LANE, J. M., MARSHALL, J. L. 1979: Meniscal degeneration due to knee instability. An experimental study in the dog. Trans. Orthop. Res. Soc. 4: 79

BEALE, B. S., HULSE, D. A. 2000: Arthroscopic-assisted stabilization of the cruciate deficient stifle in dogs using a percutaneous prosthetic ligament suture anchor technique. Proceedings of VOS annual meeting, Val'd Isére, p. 21

BRUNNBERG, L., RIEGER, I., HESSE, E. M. 1992: 7 years experience with modified over-the-top crucial ligament plastic operation in dog. Kleintierpraxis 37: 735-746

COX, J. S., NYE, C. E., SCHAEFER, W. W., WOODSTEIN, I. J. 1975: Degenerative effects of partial and total resection of the medial meniscus in dogs' knees. Clin Orthop 109: 178-183

DE ROOSTER, H., VAN RYSSEN, B., VAN BREE, H. 1998: Diagnosis of cranial cruciate ligament injury in dogs by tibial compression radiography. Vet. Rec. 142: 336-368

DE YOUNG, D., FLO, G. L., TVEDTEN, H. 1980: Experimental medial meniscectomy in dogs undergoing cranial cruciate ligament repair. J. Am. Anim. Hosp. Assoc. 16: 639

DUVAL, J. M., BUDSBERG, S. C., FLO, G. L., SAMMARCO, J. L 1999: Breed, sex, and body weight as risk factors for rupture of cranial cruciate ligament in young dogs. J. Am. Vet. Med. Assoc. 215: 811-814

FLO, G. L. 1993: Meniscal injuries. Vet. Clin. North Am. 23: 832-843

FLO, G. L., DE YOUNG, D. 1978: Meniscal injuries and medial meniscectomy in the canine stifle. J. Am. Anim. Hosp. Assoc. 14: 683

GAMBARDELLA, P. C., WALLACE, L. J., CASSIDY, F. 1981: Lateral suture technique for management of anterior cruciate ligament rupture in dogs - A retrospective study. J. Am. Anim. Hosp. Assoc. 17: 33-38

HULSE, D. A. 2001: Arthroscopic meniscal treatment. Proceedings of $1^{\text {st }}$ surgical forum ECVS, Velbert, pp. 25 28

HULSE, D. A., BEALE, B. S. 2000: Arthroscopically assisted "under and over" reconstruction of the cranial cruciate ligament in the dog. Proceedings of $1^{\text {st }}$ surgical forum ECVS, Val'd Isére, p. 22

MORGAN, J. P. 1988: Radiology of skeletal disease - Principles of diagnosis in the dog. Iowa State University Press, Ames, pp. 10-19

MORGAN, J. P. 1993: Techniques of veterinary radiography. $5^{\text {th }}$ ed. Awes, Iowa State University Press, pp. $162-163$

NEČAS, A.: Nemoci pohybového systému. In: SVOBODA, M., SENIOR, D. F., DOUBEK, J., KLIMEŠ, J. a kolektiv: Nemoci psa a kočky. II. díl., Noviko a.s., in press

NEČAS, A., ZATLOUKAL, J., KECOVÁ, H., DVOŘÁK, M. 2000: Breed predisposition of dogs to the cranial cruciate ligament rupture. Acta Vet. Brno 69: 305-310

NOBLE, J., HAMBLEN, D. 1975: The pathology of the degenerate meniscus lesion. J. Bone Joint Surg. 575: 180 PEARSON, P. T. 1971: Ligamentous and meniscal injuries of the stifle joint. Vet. Clin. North Am., 7: 489

PIERMATTEI, D. L., FLO, G. L. 1997: The stifle joint. In: PIERMATTEI, D. L., FLO, G. L.: Brinker, Piermattei and Flo's handbook of small animal orthopedics and fracture repair. W.B.Saunders, Philadelphia, pp. 516-580

SCAVELLI, T. D., SCHRADER, S. C., MATTHIESEN, D. T. 1990: Partial rupture of the cranial cruciate ligament of the stifle in dogs: 25 cases (1982-1988). J. Am. Vet. Med. Assoc. 196: 1135-1138 
SUMNER-SMITH, G. 1993: Gait analysis and orthopedic examination. In: SLATTER, D.: Textbook of Small Animal Surgery, 2nd ed., W. B. Saunders, Philadelphia, pp. 1577-1586

STONE, E. A., BETTS, C. W., RUDY R. L. 1980: Folding of the caudal horn of the medial meniscus secondary to severance of the cranial cruciate ligament. Vet. Surg. 9: 121

TIMMERMMAN, C., MEYER-LINDENBERG, A., NOLTE, I. 1998: Meniscus injuries in dogs with rupture of the cruciate ligament. Dtsch. Tierarztl. Wochenschr. 105: 374-377

VASSEUR, P. B. 1993: Stifle joint. In: SLATTER, D.: Textbook of Small Animal Surgery. $2^{\text {nd }}$ ed. W. B. Saunders, Philadelphia, pp. 1817-1865

WHITEHAIR, J. G., VASSEUR, P. B., WILLITS, N. H. 1993: Epidemiology of cranial cruciate ligament rupture in dogs. J. Am. Vet. Med. Assoc. 203: 1016-1019

ZATLOUKAL J., NEČAS, A., DVOŘÁK, M. 2000: Measurement of craniocaudal instability in stifle joints of dogs from stress radiographs. Acta Vet. Brno 69: 311-318 